\title{
Temporally Constraining Fluid Flow in Basement Shear Zones of the Athabasca Basin using Re-Os Sulfide Geochronology
}

\author{
J. TOMA ${ }^{1 *}$, R. A. CREASER ${ }^{1}$, AND D. I.PANA $\breve{~}^{2}$ \\ ${ }^{1}$ University of Alberta, Alberta, Canada (correspondence: \\ *toma@ualberta.ca) \\ ${ }^{2}$ Alberta Energy Regulator, Alberta, Canada
}

The Athabasca Basin of Western Canada is host to one of the largest uranium endowments in the world with total uranium production exceeding $20 \%$ of the global market [1]. This is in effect the result of large-scale physio-chemical processes concentrating 100 times more uranium than bulk continental crustal levels over relatively narrow, albeit uncertain, temporal scales [2,3].

Current models for $\mathrm{U}$ mineralization invoke basin-wide oxidizing uranium-rich fluids infiltrated Athabasca Basin sediment cover until a redox barrier - such as reducing fluids derived from reactivated basement shear zones (BSZ) induced uranium precipitation ca. 1.6-1.4 billion years ago [3, 4]. Athabasca BSZ, which are structurally associated with graphitic \pm pyritic assemblages, likely predate uranium mineralization by several hundred million years (5). Yet, despite playing an integral part in the genesis of the Athbasca uranium deposits, the formation and fluid-flow histories of these deep-seated faults have yet to be critically examined.

Here we present preliminary Re-Os pyrite geochronological evidence delimiting the timing of fluid flow from the Maybelle River Shear Zone on the westerly flanks of the Athabasca Basin of Alberta, Canada. Our Re-Os ages document the timing of pyrite formation to ca. $1.9 \mathrm{Ga}$, late in the Taltson orogeny, which predates peak uranium mineralization by 200-300 Ma [5]. Temporally correlating these two events provides a mechanistic answer to the formation of this, and similar, structural conduits associated with world-class uranium deposits, such as those found in the Athabasca Basin. More broadly, our preliminary findings provide a novel way for tracking the timing of fluid flow in graphitic shear zones.

[1] World Uranium Mining Production (2019), [2] Rudnick et al. (2014) Treastise on Geochemsitry, [3] Jefferson et al. (2007) Geological Survey of Canada, Bulletin 588, p. 23-67, [4] Chi et al. (2019), Nature, v. 9, p. 5530, [5] Card et al. (2007), Geolgoical Survey of Canada, Bulletin 588, p. 69-78. 